\title{
All World is Good?
}

\author{
Uttam Balu Koli \\ Maharashtra, India
}

\begin{abstract}
The meaning of the words 'world', 'good,' and 'misfortune' has been given. The hypothesis, objectives and the sources of data collection have been mentioned. The present research on the select theme of 'All world is good?' is a justification study from the perspectives of misfortunes met by characters in the select novels of Candide and The Grapes of Wrath written by Voltaire and John Steinbeck respectively. It has been concluded with the view that the world seems to be not good for those who meet many misfortunes.
\end{abstract}

Manuscript ID:

ENG-2020-08043368

Keywords: Good, Misery, Misfortune, Pessimism, Suffering and World

Volume: 8

\section{Introduction}

Issue: 4

The word 'world' means, "the earth with all its countries and people" (Dhongde 1604). The word 'good' means, "of high quality or standard, pleasant or enjoyable, suitable or convenient" (611). The word 'misfortune'

Month: September

Year: 2020

P-ISSN: 2320-2645

E-ISSN: 2582-3531

Received: 18.06 .2020

Accepted: 27.07.2020

Published: 01.09.2020

Citation:

Koli, Uttam Balu. "All World Is Good?" Shanlax International Journal of English, vol. 8, no. 4, 2020, pp. 57-63.

DOI:

https://doi.org/10.34293/

english.v8i4.3368

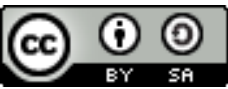

This work is licensed under a Creative Commons Attribution-ShareAlike 4.0 International License means "bad luck or disaster" (901). One expects the world to be good to live but frustrates experiencing reality. When he/she meets continuous misfortunes, he feels the world not to be good for him/her.

Repeated misfortunes create the ambiguity about the goodness of the world, which leads to the question - Is all-world good? The select theme of the present research has been justified concerning the select novels of Candide (1759) and The Grapes of Wrath (1939) written by Voltaire (French Novelist, 1694-1778) and John Steinbeck (American Novelist, 1902-1968) respectively.

\section{Hypothesis}

The world seems to be not good for those who meet many misfortunes.

\section{Objectives}

- To give the meaning of the words 'world', 'good,' and 'misfortune.'

- To provide the hypothesis.

- To write the sources of data collection.

- To justify the select theme based on the findings in the select novels.

- To draw the conclusion.

\section{Sources of Data Collection}

To test the hypothesis and attain the objectives of the present research, the sources of data collection are books, dictionaries, dissertations, internet, libraries, research journals, theses, etc.

\section{Voltaire's Candide: Findings}

In the novel Candide, the characters, Candide, Cunegonde, Dr. Pangloss, Martin, Cacambo, The Old Woman, The Baron of Thunder-ten-Tronckh, The Commander or The Baron, Jacques, Count Pococurante, Paquette, Brother Giroflee, Don Issachar, The Grand Inquisitor, Don Fernando, Mynheer Vanderdendur, The Abbe of Perigord, The Marquise of Parolignac, Six Kings, 
etc. meet many misfortunes or the situation in which they live, and act is not morally right. Some of the characters behave wrongly, opposite to the expected social norm. Is it an indication of a good world? The detailed study of the same is elaborated as follows:

\section{Candide and Misfortunes}

Candide is the central character of the novel. In the beginning, he seems to be simple, innocent, optimistic, and unfamiliar about the ways of the world. His tutor Dr. Pangloss teaches him optimism that the world is good. He moves from one place to another in the world to pursue security and to follow his beloved Cunegonde and meets many misfortunes. In the entire novel, he seems to be tested for the philosophical optimism that the world is good. His experiences and the philosopher Martin teach him pessimism only. He is the Baron's sister's illegitimate son. He is banished from adopted childhood home. He is beaten and robbed. He experiences cruelty and witnesses deaths, diseases, rapes, murders, wars, pirates, unjust executions, etc. His wealth at Eldorado attracts false friends, which becomes a cause of his suffering. Vanderdendur cheats him. He gets caught under the debris of the earthquake. He faces many misfortunes on the way of the journey, which causes a kind of disbelief over his initial optimism. He is a common man and belongs to a poor social and economic status. Because of this status, Baron's son seems to be reluctant for Cunegonde's marriage with him. This hurts him much. Though he is an honest and good-hearted man, giving money immediately to strangers and fulfilling his commitment to marry Cunegonde, he suffers a lot.

\section{Cunegonde and Misfortunes}

Cunegonde is a beautiful young lady and the daughter of Baron Thunder-ten -Tronckh. She becomes lonely as Bulgar's army kills her parents. She is exploited, raped, and made slaves and mistresses by the Bulgarian army. Later, she is sold by Bulgar's captain to Don Issachar, a Jewish banker. Don Issachar shares her with Grand Inquisitor in Portugal. Don Fernando also uses her. She suffers a lot, which causes ugliness. She finds no support. She finds human desire's futility. She believes Dr. Pangloss' philosophy, but such optimistic views also do not support her. She goes on to suffer from continuous misfortunes.

\section{Dr. Pangloss and Misfortunes}

Dr. Pangloss' seems to be a philosopher and his philosophy, "this is the best of all possible worlds" (Voltaire) states optimism. But such philosophy does not help him to find happiness in the world. Though he believes optimism, his experiences are contradictory. His philosophy is not based upon real-world evidence. When James drowns, instead of saving him, he says, "the Bay of Lisbon had been made on purpose for the Anabaptist to be drowned" (Voltaire). When Candide gets caught under the debris of the earthquake, instead of saving him, he asks for oil and wine. In the end, his positive philosophy proves to be meaningless, and he seems to be disbelieving his previous optimism. He experiences many misfortunes like Candide.

\section{Martin and Misfortunes}

Martin, a poor Dutch philosopher, seems to be flawed and cynical. He suffers a lot in his life. He travels throughout Europe with Candide. He teaches pessimism and expects only bad from the world. He says that everything in this world is for the worst. He further says about the world, "God has abandoned it to some malignant being" (Voltaire). This statement states pessimism in the world only. He often troubles knowing reality in the world.

\section{Cacambo and Misfortunes}

Cacambo is the son of a Peruvian mother and Spanish father. He lives in Spain and Latin America. $\mathrm{He}$ is the valet of Candide and travels with him in South America. He rescues Candide from many problematic situations. He helps for the reunion between Candide and Cunegonde. His philosophy seems to be opposite to the philosophy of Dr. Pangloss and Martin. He seems to be inspiring optimism, but he is not an optimist in life. He suffers from misfortunes, and his experience of the world says, "the law of nature teaches us to kill our neighbor, and such is the practice all over the world" (Voltaire), which is not a good sign of the world. 


\section{The Old Woman and Misfortunes}

The Old Woman is the illegitimate daughter of Pope and the princess of Palestrina. During the war, she witnesses slavery, rapes, cannibalism, death of fiance, etc. She suffers a lot from many misfortunes and tragedies, which cause her to be cynical. She experiences merely difficulties in life. She always seems to be closure to suicide. She works as the servant of Cunegonde. Tragically, the princess becomes a servant.

\section{Other Characters and Misfortunes}

The Baron of Thunder-ten-Tronckh is the ruler and the owner of the castle of Westphalia. He is the father of Cunegonde. He and his wife are killed by the Bulgarian army.

The Commander or the Baron is the brother of Cunegonde. During the war, the castle of his family is destroyed. He becomes a priest. He carries homosexual tendencies. Though Candide helps him, he seems to be reluctant for the marriage between Candide and his sister Cunegonde as Candide does not belong to noble and aristocrat family.

Jacques, the Dutch Anabaptist, seems to be pessimistic. He takes care of both Candide and Dr. Pangloss. He saves them. While saving a sailor, he gets drowned in the Bay of Lisbon.

Count Pococurante is a rich Venetian Senator, but the wealth causes him misfortune. He seems to be bored and unhappy with all his possessions. He also seems to be critical for everything. Candide meets him to test his philosophical optimism, but he finds Pococurante in misery.

At the outset, Paquette seems to be Cunegonde's mother's chambermaid. She maintains an affair with Dr. Pangloss and infects him with the disease. To help herself, she becomes a prostitute, and Brother Giroflee is her client. Candide gives her money in Venice when he sees her misery. She immediately squanders that all.

Brother Giroflee is forced by his parents to become a monk and increase his brother's fortune in the monastery. He leads a miserable life. He is not satisfied with his life. He maintains relations with the prostitute Paquette in Venice and pays for her service. Candide helps him by giving money, but that also does not help him to find happiness.
Don Issachar, a rich Jew merchant in Portugal, buys Cunegonde and treats her as his mistress. He shares her with Grand Inquisitor when he threatens him to burn alive. He is killed by Candide. When he is killed, his body is thrown into the gutter by society people which is a result of fanatic attitude or religious difference.

The Grand Inquisitor belongs to the Portuguese Catholic Church. He is a hypocrite. It is the result of his threat that Issachar shares Cunegonde with him. He is killed by Candide.

Don Fernando, the governor of Buenos Aires, gets infatuated by Cunegonde. He aggressively steals her from Candide and makes his mistress.

Mynheer Vanderdendur is a Dutch merchant and owner of slaves. He is cruel and unscrupulous. He cheats Candide and steals his jewel laden sheep in Suriname. He is killed in battle, and his death seems to be a sign of having justice in the world.

The Abbe of Perigord is a Paris socialite. He cheats Candide for money by writing fake letters and arranging a fake reunion between Candide and Cunegonde.

The Marquise of Parolignac is a Paris socialite. She is a sexually licentious and cunning woman. She steals Candide's jeweled rings. She also seduces him.

Candide meets Six Kings at dinner in Venice. It is their misfortune that they all are dethroned and exiled.

\section{John Steinbeck's The Grapes of Wrath: Findings}

In the novel The Grapes of Wrath, the Share Croppers / Migrants, Joad Family (Ma Joad, Pa Joad, Grampa Joad, Granma Joad, Noah Joad, Tom Joad, Rose of Sharon, Connie Rivers, Uncle John), Muley Graves, The Mayor, Hungry Children, etc. meet many misfortunes. Their misfortune seems to be the result of other misbehavior or ill-nature. Does this show the picture of a good world? The detailed study of the same is elaborated as follows:

\section{Share Croppers / Migrants and Misfortunes}

The share croppers face ruinous conditions. Nature is unfavorable to them. The drought affects them. Lack of rainfall, hot sun, and fast wind with dust ruin crops. The share croppers are frustrated. 
They have no land and are only tenant farmers. They put with them their share of the crop only. The rest of the crop is given to the owners like finance companies, banks, and to pay taxes. The land owners are cruel. They are unwilling to continue the tenant's share. They think it is their margin of profit. They plan to develop a big farm connecting all small pieces and tractor out families. They do not think for share cropper's loss of their source of livelihood. The share croppers are afraid of all this. They are frustrated, realizing their starvation. They ask for some time to leave the traditional way of farming but are rejected. They protest and say:

But it's our land. We measured it and broke it up.

We were born on it, and we got killed on it, died on it. Even if it's no good, it's still ours. That's what makes it ours being born on it, working it, dying on it. That makes ownership, not a paper with numbers on it. (Steinbeck)

It is their great misfortune that "the tractors moved in and pushed the tenants out" (Steinbeck). The tractors crush the houses, and drivers look like robots. The share croppers leave homes. They are powerless and are merely victims. The banks override them and issue notices. Everything is demolished. The share croppers are refused to enter on scoured land. They are helpless. They lose their hope of labor. At the beginning, they drive, "One man, one family" (Steinbeck). But later, thousands of families are driven. They say, "I lost my land" (Steinbeck). Later, which becomes, "We lost our land" (Steinbeck). They are reluctant to leave the land. They sell farm equipment and animals at cheap rate. They burry unhappily the things in the yard which they cannot carry. They do this because they have memories of these things.

While migrating to California, they witness many misfortunes. They need means of transportation, but the opportunist businessmen harass them by taking disadvantages of their bad situation. These businessmen are profit-oriented. Before delivery, they remove a good battery from the car. They add sawdust in the exhaust system. They bargain knowing well that the share croppers / migrants badly need cars, and as they are poor and uneducated, it will be easy to deal with their complaints. Therefore, they loot them.
The share croppers / migrants believe that California is good but frustrate knowing reality. On the way, each one confesses to them that the California border patrol does not permit anybody to enter in and requests them for a return journey.

In California, the situation is worse. Though the environment is supportive, people have no money. The employers are cruel-hearted. They attract reserve labor. They cut wages. They show scarcity of fruits and increase prices. They cheat poor migrants. The migrants get work of low value. They suffer from starvation. Dead babies are born. Joblessness and homelessness defeat them. They lose everything and are insulted by calling Okie.

Okie use' to mean you was from Oklahoma. Now it means you're a dirty son-of-a-bitch. Okie means you're scum. Don't mean nothing itself; it's the way they say it. (Steinbeck)

They suffer from deep misery. They experience only hate. They swarm property; they cannot contribute; they cannot spend, and they reduce wages and become competitors for local people. Therefore, they are hated by owners, bankers, store keepers, and laboring natives. They are refused school entry. They find there everything unreasonable. They move for foods as the ants do. The agents, black listers, and spies harass them. They suffer from a lack of amusement. They pray and try to settle down in the current situation. Their life occupies with anger and frustration. The availability of many workers causes insufficient work. The poor migrants are unable to save money; are unable to eat meat, and think continuously about their survival.

They suffer from the flood situation in California also. Their tents and cars are surrounded by water. To get out of it, they find no relief fund. The natives trouble them. They try to dispossess them. They assume that the poor migrants will come together and revolt. Therefore, they keep them deliberately away from work. They mislead them with false advertisements. Some try to stand against this but are put in jail. They try to extinguish the revolt by applying all means. They reduce wages. They have a fear that if the migrants stay in one place for a long time, they will organize and revolt. They plan to close the government camps wherein the deputies are not permitted to enter and also as the people have 
liberty and cannot be arrested without a warrant. It is the painful existence of poor share croppers / migrants.

\section{Joad Family and Misfortune}

The Joad family is a representative family which suffers from many misfortunes. Prolonged drought and mechanization of farm force them to leave the land and house and go in search of food and employment to California. The family is merely the victim of the soulless system and suffers from starvation. It witnesses the extreme economic depression and finds exploitation only. The members of it are tired. The lack of money and work frustrates them. They plan to go to some other places, but their entry is rejected. The misfortune merely to be tolerated. The Joad family witnesses the same worse situation both at California and Oklahoma. The family falls apart on the way of journey to California. The family loses much than gaining something. They suffer from the lack of work, lack of money, lack of food, lack of status, low payment, and lowquality food at high prices. The summary of some select family members, who meet misfortunes, is as follows:

\section{Ma Joad and Misfortunes}

Ma Joad seems to be the main strength of the family and tries to keep it united in a very tough time. She witnesses many misfortunes. Rather, she can be called the mother of sorrows. She suffers a lot, and the story moves around her. Tom's imprisonment depresses her much. Split up of her family pains her much. Granpa departs; Noah, her elder son, wanders away in the river; her son, Al leaves the family to stay with his beloved; Connie, her son-in-law, abandons the family; and Tom, the main support of the family, departs. She utters, "Family's fallin' apart" (Steinbeck). Granma's death disturbs her. Due to the lack of money, she cannot fulfill Granma's last wish of proper burial, which pushes her in agony. Her family members, one after another, pass away, which affects her much. Unexpected blows cause her misery. We see tears in her eyes on Tom's departure. She worries for Winfield, the youngest of Joad Children, for his upbringing without a proper home and seems afraid of his being wild.

\section{Pa Joad and Misfortunes}

Pa Joad, a tenant farmer in Oklahoma, is evicted from farm. He is a thoughtful man who plans well on their California trip. He suffers a lot, realizing the hardship being faced by the family. He frustrates, realizing his efforts falling short of protecting his family. He seems to be helpless to find work in California, which makes him upset. He is a family leader, and his inability makes him ineffective in his role in the family. His wife criticizes him for losing responsibility to protect the family. He seems to be broken and fails to prevent the shelter of the family from flood and makes himself ready to follow his wife blindly. He witnesses gradual deterioration. He feels ashamed of his weak situation. Ruthies' disclosing of the fact causes Tom's departure, which depresses him much.

\section{Grampa Joad and Misfortunes}

Grampa is the grandfather of Tom. He is the founder of the Joad farm. He is old, and his death is tragic. He loves his native land. He seems to be reluctant to leave it, but he has to quit it due to unfavorable circumstances which leads to his immediate death on the way of journey. He cries when Sairy Wilson lets him sleep on mattress. He suffers from stoke and gets suffocated. Casy prays for him but before the end of the prayer, he dies. Due to the lack of money, the family members themselves bury him. When they talk about his death, Casy says, "Grampa didn't die tonight. He died the minute you took 'im off the place" (Steinbeck).

\section{Granma Joad and Misfortunes}

Granma is the grandmother of Tom. She is an older woman and her husband's death affects her much, which causes her to deteriorate her health. She too dies soon and gets no proper burial, which is her misfortune.

\section{Noah Joad and Misfortunes}

Noah Joad is the eldest son of the Joad family. He seems to be slightly deformed since childhood, and it is the result caused by his father during his birth. He regrets not being loved by parents. He leaves the family first to live his life in isolation away from society people on his own. He plans to catch fish and support himself. 


\section{Tom Joad and Misfortunes}

Tom, the central character of the novel, is the second son of the Joad family. He seems to be the key person in the family. He meets many misfortunes and faces hardship and hostility. When he goes home after relieving from custody, he sees home in worse condition occupied by cats and rats. The news from Muley Graves, his neighbor, that his family members have to leave home and land due to land owner's pressure saddens him. The destruction troubles him. When the contractor and deputy try to deceive his family offering work at Tulare and, if not accepted, threatening to burn camp sites, he and Casy try to bit them. He plans to stand against injustice, but family members insist on him to keep patience. He is not a free person and, most of the time hide himself.

\section{Rose of Sharon and Misfortunes}

Rose of Sharon is the eldest daughter of the Joad family. She is the wife of Connie. She dreams for a good life with her husband and child but gets disillusioned by witnessing reality. She seems to be immature. She suffers from harsh realities. She is abandoned by her husband. The selfishness of her husband surprises her and brings stress. She is pregnant. Mrs. Sandry is a mad woman who frightens her. She says:

You're hell-burnin' sinners, all of you! I can see your black soul a- burnin'. I can see that innocent child in that there girl's belly a-burnin' (Steinbeck).

She becomes nervous by her saying and thinks about her baby. Later, she delivers a dead baby. It is a result of harassment and starvation. It is the misfortune not only of herself but also of her baby.

\section{Connie Rivers and Misfortunes}

Connie Rivers is the husband of Rose of Sharon. $\mathrm{He}$ is selfish and immature. He dreams for a good life and better job opportunities at California but frustrates realizing reality. He abandons his wife and Joad family out of frustration, which is a result of their arduous journey. The harshness in the journey causes him to lose hope. He repeatedly thinks for his stay at Oklahoma. He is hurt emotionally.

\section{Uncle John and Misfortunes}

Uncle John is the uncle of Tom. It is his misfortune that he becomes a widower losing his young wife who happens merely due to his ignorance. His wife, being pregnant, suffers from stomachache. He ignores, and his wife dies due to the appendix. After her death, he has to live alone. He does not forgive himself for her death, and he sees his negligence as a $\sin$. He feels guilty continuously for the same, which leads to binge prostitutes and alcohol. He considers himself as the main cause of the misfortune of his family.

\section{Other Characters and Misfortunes}

Muley Graves is the neighbor of the Joad family at Oklahoma. He is dispossessed but refuses to leave the land. His family members go to California, leaving behind him. He alone stays. He has no food. He kills chickens, rabbits, squirrels, and raccoons. He sleeps anywhere. He lives as ghosts do. He remembers boyhood, the place of meeting first love, and the room of first son's birth. He is frustrated knowing the landowner's cruelty. He hates them.

The Mayor is the old migrant worker. California police continuously torture him, which shows his misfortune.

Hungry Children starve a lot. They surround Ma's tent as they smell her cooking. Ma gives them food. The children suffer from the lack of sufficient food at the land.

\section{Conclusion}

The answer to the question - Is the world good for all these characters in the select novels of Candide and The Grapes of Wrath? Is, of course, 'no.' Some of the characters in the select novels meet many misfortunes caused by other's misbehavior or illnature. Some other character's wrong behavior and actions invite misfortunes for themselves. In short, each one in the select novels seems to be either in problems or morally wrong. The happenings with them are not ethically appropriate, which do not indicate a good sign about the world. It is merely the projection of the unfavorable situations in the world, causing misfortunes to the characters. No doubt, the world is made up of by human beings only, and their behavior and actions merely decide the standard of 
the world - either good or bad. Sometimes natural calamity interferes, but the sole things are dependent upon human beings. Most misfortunes are caused by misbehaviours and ill natures than natural disasters. The world seems to be good for those who find happiness and not good who find misfortunes. Therefore, to conclude, it is stated that the world seems to be not good for those who meet many misfortunes.

\section{References}

Dhongde, Ramesh. Oxford English - English Marathi Dictionary, Oxford University Press, 2016.

Kothari, C. R. and Gaurav Garg. Research Methodology: Methods and Techniques, New Age International (P) Ltd., 2010.

MLA Handbook $8^{\text {th }}$ edition, Modern Language Association, 2016.

Steinbeck, John. The Grapes of Wrath, Penguin, 2006.

Voltaire. Candide, Penguin, 2006.

\section{Author Details}

Dr. Uttam Balu Koli, Maharashtra, India, Email ID: druttamkoli@gmail.com. 